\title{
Bir Afet Olarak Küresel İklim Değişikliği ve İlkokul Öğretmenlerinin İklim Değişikliği Farkındalığının İncelenmesi: Gümüșhane İli Örneği
}

The Investigation of Global Climate Change as a Disaster and the Global Climate Change Awareness of Primary School Teachers: Sample of Gümüşhane Province

\author{
Meryem AKBULUT ${ }^{1}$, Afşin Ahmet KAYA ${ }^{2}$
}

\section{ÖZ}

Küresel iklim değişikliğinin afet olarak önemi ve günümüzdeki en önemli çevre sorunlarından biri olması, bizi küresel iklim değişikliğiyle ilgili bilime katkı sağlayacak bir çalışma yapmaya yöneltmiştir. Araştırma kapsamında öncelikle afetlere, ardından küresel iklim değişikliğiyle ilgili genel bir literatür araştırmasına yer verilmiştir. Araştırma kapsamında ilkokul öğretmenlerinin iklim değişikliği farkındalığını ölçmek için, inanç, tutum, davranış ve bilgi alt boyutlarından oluşan bir farkındalık ölçeği kullanılmıştır. Araştırmanın evrenini Gümüşhane ilinde görev yapan toplamda 300 ilkokul öğretmeni oluşturmaktadır. Veri toplama sürecinin sonunda 214 ilkokul öğretmenine ulaşılmıştır. Çalışmanın verileri Amos 23 ve SPSS 21 paket programlarında analiz edilmiştir. Ortaya çıkan sonuçlar Gümüşhane ilinde görev yapan ilkokul öğretmenlerinin iklim değişikliği farkındalıklarının yüksek olduğunu göstermektedir. Bu durum araştırmanın amaçlarından olan iklim değişikliği farkındalığı yüksek bireyler yetişmesi açısından önem arz etmektedir. Son olarak tartışma, öneri ve sonuç başlıklarıyla genel bir değerlendirme yapılmıştır ve küresel iklim değişiklinin önemine dikkat çekilmiştir.

Anahtar Kelimeler: Afet, İlkokul Öğretmenleri, Küresel İklim Değişikliği.

\begin{abstract}
The importance of global climate change as a disaster and being one of the most important environmental problems today has led us to make a study that will contribute to science related to global climate change. Within the scope of the research, firstly disasters and then a general literature research about global climate change are included. Within the scope of the research, an awareness scale consisting of belief, attitude, behavior and knowledge sub-dimensions was used to measure the awareness of primary school teachers on climate change. The universe of the research consists of 300 primary school teachers working in Gümüşhane province. At the end of the data collection process, 214 primary school teachers were reached. The data of the study were analyzed in Amos 23 and SPSS 21 package programs. The resulting results show that primary school teachers working in Gümüşhane province have high awareness of climate change. This situation is important for raising individuals with high climate change awareness, which is one of the aims of the research. Finally, a general evaluation has been made with the topics of discussion, suggestions and conclusions and attention has been drawn to the importance of global climate change.
\end{abstract}

Keywords: Disaster, Primary School Teachers, Global Climate Change.

\footnotetext{
*Bu çalışma yüksek lisans tezinden türetilmiştir. Araştırmanın yürütülebilmesi için Gümüşhane Üniversitesi Bilimsel Araştırma ve Yayın Etiğ Kurulu'ndan gerekli onay (Karar No: 30.10.2018-2018/8) alınmıştır.

${ }^{1}$ Öğr. Gör., Yozgat Bozok Üniversitesi, Çekerek Fuat Oktay Sağlık Hizmetleri Meslek Yüksekokulu, İlk ve Acil Yardım Bölümü, meryem.akbulut@bozok.edu.tr, ORCID: 0000-0002-1299-7421

${ }^{2}$ Doç. Dr., Gümüşhane Üniversitesi Sağlık Bilimleri Fakültesi, Acil Yardım ve Afet Yönetimi Bölümü, afsinakaya@gumushane.edu.tr, ORCID:0000-0003-2082-6478
} 


\section{GíRIŞ}

Küresel iklim değişikliğinin olumsuz etkileri her geçen gün daha fazla hissedilmeye başlanmıştır. Dünyanın her yerinde artan sıcaklıklar ve ekstrem hava olayları günlük yaşamı zorlaştırmakta ve insanları çaresizliğe sürüklemektedir. İklim değişikliğinin afetsellik boyutuna baktığımızda gözümüze çarpan en önemli özelliği yavaş ilerlemesi ve sonuçlarıyla oldukça yıkıcı bir afet olmasıdır. ${ }^{1}$

İklim değişikliği sürecine baktığımız zaman en önemli göstergeler iklim parametreleri üzerinde olduğu görülmektedir. Bu iklim parametreleri; sıcaklık, yağış, nem, deniz seviyesi vb. değişkenler üzerinde etki göstermektedir. Özellikle yeryüzünde insani faaliyetler arttığından beri iklim değişikliğinin kanıtları daha çok ortaya çıkmaya başlamıştır. ${ }^{2}$ Örneklerine bakacak olursak;

$\begin{array}{lccr}\bullet & \text { Dünya } & \text { sıcaklı̆̆g } & 1906-2005 \\ \text { yılları arasında } & 0,74^{\circ} \mathrm{C}^{\prime} l i k & \text { artış } \\ \text { göstermesi } & \end{array}$

- Buzulların eriyerek, kutuplara doğru çekilmesi ile birlikte yüksek dağların tepelerindeki buzulların ve kar örtüsünün azalması,

- Sicak havayı ve suyu seven tropikal bitki ve balıkların kutuplara doğru yayılmas1,

Artan iklim göçmenleri ve mülteci problemleri,

Havadaki kirleticilere karşı hassas olan narin kuş türlerinin azalması,

- A Ağaçlardaki yaş halkalarının daha hılı bir büyüme göstermesi,

- $\quad$ Son 1400 yilın en sicak yilları olarak kabul edilen 1990'lı yılların ardı sira gelmesi ${ }^{4}$,

$\begin{array}{lll}\bullet \quad \text { Buharlaşma ve } & \text { yağış } \\ \text { oranlarında artış, } & & \\ \bullet \quad \text { Yağışların } & \text { büyük } \\ \text { çoğunluğunun sağanak olması, } & \\ \bullet \quad \text { Tundralarda oluşan } & \text { erime } \\ \text { (Kuzey Kutbu Bozkırı), } & & \end{array}$
beyazlaşma ${ }^{5}$,

Mercan resiflerinde görülen

Küresel ortalama deniz seviyesi değişimi, gel-git oranları ve su seviyesi ölçüm kayıtlarına göre 19. yüzyıldan günümüze kadar 10-25 cm civarında yükselmiştir. ${ }^{6} \mathrm{Bu}$ yükselme mevcut sıcaklık artışıyla ilişkilidir. ${ }^{7}$ Sonuç olarak iklim değişikliğinin yarattığ domino etkisi ortadadır. Sıcaklık artışları arktik ve antartika buzullarını tetiklemiş ve erime sonucunda deniz seviyesinde artış meydana gelmiştir ${ }^{2}$,

- Yağış rejiminde meydana gelen değişimlere detaylı olarak bakıldığında, Kuzey yarımkürede kış aylarında artış göstermiştir. 1960’lı yılların sonuna doğru ise subtropikal ve tropikal kuşakların yağış rejiminde azalma görülmüştür. $\mathrm{Bu}$ değişim tatlı su kaynakları, tarıma ve topluma etki etmiştir. Örneğin, Afrika'nın Sahel bölgesinde yağışların azalmasıyla kuraklık baş göstermiş ve milyonlarca insan göç etmek zorunda kalmıştır. Ayrıca milyonlarca hayvanın ölmesine neden olmuştur. Genele bakıldığında kuraklığın 1973, 1977, 1989 ve 1990'lı yillarda şiddetli oranda yaşandığı görülmektedir. Karasal iklime sahip olan bölgelerde ise ilkbahar ve yaz mevsiminde artış görülmüştür ${ }^{7}$,

- Dördüncü önemli gösterge ise stratosfer sıcaklığında yaşanan azalmadır. Özellikle son yıllarda zararlı kimyasallarda meydana gelen artışla sıcaklık değerlerinde düşmeler yaşanmıştır. Sicaklık değerlerinin düşmesi, katmanın içindeki hava sirkülasyonunu azaltarak hava kirliliğinin artmasına neden olmaktadır Stratosfer tabakasının ortalama sıcaklığında yaşanan azalma iklim değişikliğinin bir başka önemli göstergesidir. Sicaklığın düşmesiyle, hava sirkülasyonu azalır, sanayi devriminden sonra havadaki zararlı maddelerin artışına bağlı olarak hava kirliliğinde artış olmuştur. ${ }^{8}$ 
Yukarıda bahsedilen örnekler iklim değişikliğinin varlığına dair birer kanıt niteliği taşımaktadır.

Günümüze bakıldığında iklim değișikliğini artıran etkenlerde hızlı bir yükseliş olduğu göze çarpmaktadır. Örneğin; sera gazı emisyonlarının artışı, nüfus artışı, sanayileşme, fosil yakıtlar ve beraberinde getirdiği kirlilik iklim değişikliğini hızlandırmıştır. $\mathrm{Bu}$ artışın ilk sorumlusu ise insan faaliyetleridir. Doğa üzerinde yapılan tahribat mevcut dengeyi bozmuș ve insanlara ciddi zararlar vermeye başlamıştır. İklim değişikliğinin sebep olduğu olumsuz etkiler, geçmişten günümüze kadar insanları çaresiz bırakmış ve zarar verme potansiyeli yüksek olaylara neden olmuştur. ${ }^{9}$ Gerekli tedbirler yetersiz kaldığından, çevresel sorunların önüne geçmek gün geçtikçe daha zor bir hal almiştır.

Ortaya çıkan etkiler çevresel bir sorun olmanın ötesine geçmiştir. İklim değişikliğinin ekosisteme, havaya ve suya olan olumsuz etkileri sosyal ve ekonomik durumu bozmuş, insan sağlığını etkilemiş, göçlere, tarımda verimsizliğe, çölleşmeye vb. pek çok kötü sonuca sebep olmuştur. Sonuç olarak yarattığ 1 her olumsuz durum ardından ikincil bir afet olarak karşımıza çıkmaktadır. Üstelik dünyanın her yerinde ortaya çıkan sorunlar, bu küresel afete küresel çapta önlemler alınması gerektiğini göstermektedir. ${ }^{10}$

Yaşanılan durum karşısında, ortak bir şekilde paylaşılan dünyaya verilen zarara karşı alınacak önlemler noktasında tüm bireylere aynı oranda sorumluluk düşmektedir. Özellikle iklim değişikliğinin ilerlemesinde büyük rol sahibi ülkeler elini taşın altına koyma noktasında öncü olmalıdır. Çünkü risk, iyi bir şekilde yönetilmezse, kriz evresinde geri dönülemez sonuçlar doğuracaktır. ${ }^{11,12}$

Tarihsel süreçte yapılan araştırmaların çoğu, iklim değişikliğinin varlığını ifade etmiştir. Genel olarak bir sonraki çalışma diğerini bilimsel yöntemlerle destekler nitelikte olmuştur. Tüm bunlara bakıldığında uzun süredir iklim değişikliği ile beraber yaşadığımız, fakat sürekli olarak göz ardı edildiği ortaya çıkmaktadır. Şu anki durum ise, ortalama sicaklığ $11^{\circ} \mathrm{C}$ artmış bir dünyadır. $\mathrm{Bu}$ durum zorunlu olarak tüm insanlığı tedbir almaya yönlendirmektedir. ${ }^{13}$

İklim değișikliğine bağlı daha fazla afetle ve beraberinde getirdiği sorunlarla karşılaşmamak için güçlü önlemler alınmalı ve bu aşama çok hızlı olmalıdır. $\mathrm{Bu}$ önlemlerin başında; sera gazı salınımın azaltılması, yenilenebilir enerji kaynaklarına geçiş, fosil yakıt kullanımını en aza indirmek, tüm bireylerin iklim değișikliği farkındalığını arttırmak ve risk aşamasını bireyden başlayarak küresel düzeye doğru mümkün olduğunca düzgün ve etkili bir şekilde ilerletmek ana amaçlardan olmalıdır. ${ }^{11}$

$\mathrm{Bu}$ afete karşı koyabilmek için, perde arkasında bulunan gerçeğe karşı faaliyetlere başlanmalıdır. Geleceğe yönelik yapılan tahminler de gerçeğin oldukça ürkütücü olduğunu göstermektedir. Çözüme yönelmekte daha fazla geç kalınmamalıdır. Marx 'insanlar sadece çözebilecekleri sorunları belirler' ifadesinden yola çıkarsak ve iklim değişikliğinin belirlenmiş ancak çözülememiş bir sorun olduğunu göz önünde bulundurursak, çözümün insan gücünde aranması gerektiği ortaya çıkmaktadır. ${ }^{14}$

Çevreye yönelik tutumu ve sorumluluk bilincini geliştirmede okullar önemli bir paydaştır. ${ }^{15}$ İklim değişikliğiyle mücadelede en önemli basamak olarak görülen eğitime bu konuda önemli sorumluluklar düşmektedir. Ciddi bir çevre problemi olan bu afete karș1 gereken eğitim okullarda başlamalıdır. Çünkü çevreyle ilgili verilecek eğitim okul öncesinde başlamalı ve yaşam boyu devam etmelidir. Eğitim, sayesinde iklim değişikliğinin etkileri önemli ölçüde azalacaktır. ${ }^{15}$

Sonuç olarak tüm dünyayı etkileyen iklim değişikliği krizi herkesi önlem almaya yönlendirmiştir. İklim değişikliği, hükümetleri planlara, konferanslara ve anlaşmalara yönlendirmiştir. Tüm bu gelişmeler geleceğe güvenle bakmamızı sağlamaktadır. Fakat tamamlanması gereken eksikler vardır ve bunun için çaba sarf edilmesi gereklidir. Eksikliklerin tamamlanması için acele edilmelidir. Çünkü yapılan bilimsel çalışmalar iklim 

değişikliğinin varlığını ispatlamış ve
iklimlerin değişimine ilişkin belirsizliği ortadan kaldırmıştır. Artık yapılması gereken, iklim değişikliğinin varlığına dair şüpheyi bırakmak ve geleceğe yönelik düzgün adımlar atmaktır.

\section{MATERYAL VE METOT}

\section{Araştırmanın Türü}

Araştırma, tanımlayıcı tipte bir çalışmadır.

\section{Araştırmanın Yeri ve Zamanı}

$\mathrm{Bu}$ araştırma 2018-2019 eğitim-öğretim yılında Gümüşhane il merkezi, ilçeleri ve köylerinde faaliyet gösteren ilkokullarda yapılmıştır. Araştırmanın anket uygulama süreci 01.11.2019-31.11.2019 tarihleri arasıdir.

\section{Araştırmanın Evren ve Örneklemi}

Çalışmanın evrenini Gümüşhane ilinde 2018-2019 eğitim öğretim yılında toplamda 52 ilkokulda görev yapan 214 sinıf öğretmeni oluşturmaktadır. Katılımcılar sadece birinci, ikinci, üçüncü ve dördüncü sınıflarda eğitim veren ilkokul öğretmenleridir. Branş, lise ve anaokulu öğretmenleri çalışmaya dahil edilmemiştir. Veri toplama süreci gönüllü öğretmenlerin katılımıyla tamamlanmıștır.

\section{Veri Toplama Araçları}

Araştırmanın verileri HİĞDE tarafından 2014 yılında 'Fen Bilimler Öğretmen Adaylarının Çevre Dostu Davranışlarının Belirlenmesi: İklim Değişikliği Örneği", isimli yüksek lisans tezinde kullanılan ölçek kullanılarak toplanmıştır. ${ }^{16}$ Araştırmada kullanılan veri toplama aracı uzman görüşü alınarak düzenlenmiştir. Belirsizlik İnançları alt boyutundan 13 soru, Çevre Dostu Davranış alt boyutundan 9 soru, Epistemik İnançlar alt boyutundan 9 soru, Bilgi alt boyutundan 11 soru, Çevreye Yönelik Tutum alt boyutundan 7 soru kullanılmıştır. Ölçeğin demografik bilgi kısmı ile Sorumluluk bölümleri de çalışmaya eklenerek kullanılmıştır.

\section{Verilerin Toplanması}

Araştırma boyunca Gümüşhane ilinde devlet kurumlarında görev yapan ilkokul öğretmenleriyle hafta içi ders aralarında iletişim kurularak gönüllü öğretmenlere uygulanmıştır. Anketlerin bir katılımcı tarafından doldurulma süresi 15-20 dakika civarında olmuştur.

\section{Verilerin Değerlendirilmesi}

Araştırmanın analizinde AMOS 23 ve SPSS 21 paket programı kullanılmıştır. Araştırma analizlerinde tanımlayıcı istatistiksel metotlarin (ortalama, standart sapma vb.) yanı sira niceliksel verilerin karşılaştırılmasında, grupların dağılımları varyans analizi ile değerlendirilmiş, normal dağ 11 ım gösteren parametrelerin gruplar arası karşılaştırmaları yapılmıştır. Ölçeklerin analizi sonucunda elde edilen puan ortalamalarında ilişkisel değerlendirmede korelasyon analizi, etki değerlendirmesinde regresyon analizi kullanılmıştır. Güvenirlik için Reliability Analysis kullanılmıştır. Anlamlılık değeri $\mathrm{p}<0,05$ düzeyinde değerlendirilmiştir.

\section{Araştırmanın Etik Yönü}

Araştırmanın yürütülebilmesi için Gümüşhane Üniversitesi Bilimsel Araştırma ve Yayın Etiği Kurulu'ndan gerekli onay (Karar No: 30.10.2018-2018/8) alınmıştır. Araştırmanın gerçekleştirildiği Gümüşhane İl Milli Eğitim Müdürlügünden Kurum izni (28.11.2018 tarih ve 22804017say1) alınmıştır. Ölçek izin bilgisi elektronik posta yolun ile alınmıștır. Okullarda uygulanan anket formlarına dönütler çeşitli sebeplerden dolayı (hastalık, gönülsüzlük, yıllık veya idari izin vb.) örneklemin tamamına ulaşılamamasına neden olmuştur. Buda araştırmanın sınırlılıklarıdır. 


\section{BULGULAR VE TARTIŞMA}

Çalışma, 49 soru üzerinden güvenirlik analizine tabi tutulması sonucu Cronbach's Alfa değeri ,848 olarak bulunmuştur. Ölçek geliştirme uyarlama çalışmalarında Cronbach's Alfa değerinin en az ,700 ve üzeri olması gerektiği genel olarak kabul görmektedir. ${ }^{17}$ Sonuç olarak veri toplama aracı olarak kullandığımız ölçek güvenilirdir. Şekil 1'de araştırma modeli verilmiştir.

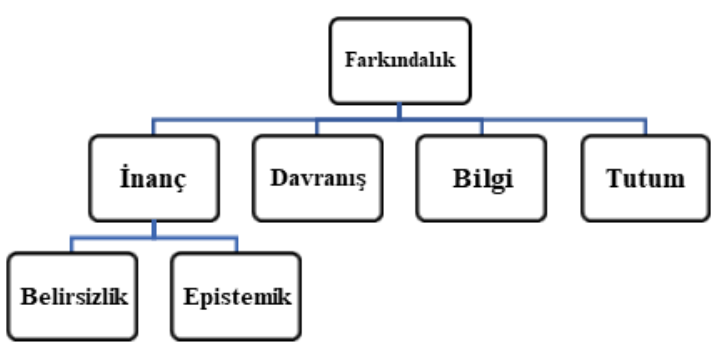

\section{Şekil 1. Araştırma Modeli ${ }^{16}$}

Araştırma sonunda AMOS 23 programında analiz ettiğimiz verilere göre doğrulayıcı faktör analizine ilişkin bilgiler şu şekildedir; RMSEA'nın bir diğer adı kötü uyum indeksidir. RMSEA, uyum ölçütlerinde 0,08 'in altında bulunan değerler makul değer olarak kabul görürken, 0,05 'in altında bulunan değerler ise mükemmel uyum olarak kabul edilmektedir. Ayrıca 0 değeri mükemmel uyum gösterir. ${ }^{18,19}$ Çalışmamızda bu oran 0,04 olarak bulunmuştur ve mükemmel uyum göstermektedir.

CFI, özelleştirilmiş olan modele yönelik uyum fonksiyonunun, temel alınmış olan bir başka modelden elde edilen uyum fonksiyonlarının karşılaştırılmasıdır. ${ }^{18} \mathrm{CFI}$, 01 aralığında değer alır. Yüksek değerler iyi uyum olduğunu gösterir. Model, 0,90'dan yukarı iyi uyum gösterir. ${ }^{20}$ Çalışmamız, 0,91 değeri ile iyi uyum aralığındadır.

GFI, tanımlayıc1 uyum indeksidir. Açıklanmış olan genel varyans oranının toplam genelleştirilmiş varyansa oranıdır. GFI indeksi 0 ile 1 arasında değer almaktadır. 1'e yakın değerler iyi uyum olduğunu gösterir. ${ }^{21}$ Çalışmamız kabul edilebilir uyum değerleri arasindadir.

RMR, modelin parametrelerinde tahmin yapilırken, kovaryans matrisleri arasında kalmış olan çelişkileri ifade eder. Uyumlu artıklar şeklinde de isimlendirilir. RMR, 0 ile 1 arasında değer almaktadır ve 0 'a yaklaştıkça iyi uyumu gösterir. ${ }^{22}$ Çalışmamız iyi uyum değerleri içerisindedir.

TLI, bu indeks NNFI olarak da bilinir. Bu eşitlikte 0,95 ve üzeri iyi bir uyumu gösterirken, 0,90 üzerindeki değerler kabul edilebilir bir uyum olduğunun göstergesidir. ${ }^{18}$ Çalışmamız 0,90 değeri ile iyi uyum göstermektedir.

IFI, Bollen'in artan uyum indeksi BL89 olarak da bilinir. 0 ve 1 arasında değer alır. $\mathrm{Bu}$ eşitlikte 0,95 ve üzeri iyi bir uyum gösterirken, 0,90 üzerindeki değerler kabul edilebilir bir uyum göstergesidir. ${ }^{18}$ Araştırmamız, kabul edilebilir uyum değerleri arasindadir.

$\chi 2 / \mathrm{sd}, \mathrm{bu}$ indeks $\chi 2$ 'nin serbestlik derecesine bölünmesi sonucunda elde edilir. $\mathrm{Bu}$ değer iki veya altında mükemmel uyumun olduğunu gösterir. Beş ve daha az bir değerin altında olduğunda kabul edilebilir bir değerdir. ${ }^{20,23}$ Araştırma sonuçlarımıza göre bu değer mükemmel uyum göstermektedir. Sonuçlarımıza genel olarak baktığımızda, araştırma modelimiz doğrulanmaktadır. Tablo 1'de detaylı DFA tablosu verilmiştir.

Tablo 1. Doğrulayıcı Faktör Analizine İlişkin Bulgular 24, 25

\begin{tabular}{|c|c|c|c|c|}
\hline $\begin{array}{l}\text { Inde } \\
x\end{array}$ & $\begin{array}{c}\text { Mükemmel } \\
\text { Uyum } \\
\text { Ölçütü }\end{array}$ & $\begin{array}{l}\text { Kabul } \\
\text { Edilebilir } \\
\text { Uyum } \\
\text { Ölçüitü }\end{array}$ & $\begin{array}{c}\text { Araştırm } \\
\text { a } \\
\text { Bulgusu }\end{array}$ & Sonuç \\
\hline$\frac{\chi^{2}}{s d}$ & $0-3$ & $3-5$ & 1,40 & Mükemmel Uyum \\
\hline $\begin{array}{l}\text { RMSE } \\
\text { A }\end{array}$ & $\begin{array}{l}, 00 \leq \text { RMSEA } \leq \\
, 05\end{array}$ & $\begin{array}{l}, 05 \leq \text { RMSEA } \leq \\
, 10\end{array}$ & ,04 & Mükemmel Uyum \\
\hline CFI & $, 95 \leq \mathrm{CFI} \leq 1,00$ &, $90 \leq \mathrm{CFI} \leq, 95$ &, 91 & İyi uyum \\
\hline TLI & $, 95 \leq \mathrm{TLI} \leq 1,00$ &, $90 \leq \mathrm{TLI} \leq, 95$ & ,90 & İyi uyum \\
\hline GFI & $, 95 \leq \mathrm{GFI} \leq 1,00$ &, $90 \leq \mathrm{GFI} \leq, 94$ &, 81 & $\begin{array}{l}\text { Kabul } \\
\text { uyum }\end{array}$ \\
\hline $\begin{array}{l}\text { RMR } \\
\text { IFI }\end{array}$ & $\begin{array}{l}, 00 \leq \mathrm{SRMR} \leq, 05 \\
, 95 \leq \mathrm{IFI} \leq 1,00\end{array}$ & $\begin{array}{l}, 05 \leq \mathrm{SRMR} \leq, 08 \\
, 90 \leq \mathrm{IFI} \leq, 95\end{array}$ & $\begin{array}{l}, 05 \\
, 91\end{array}$ & $\begin{array}{l}\text { İyi Uyum } \\
\text { İyi Uyum }\end{array}$ \\
\hline
\end{tabular}

Araştırmanın sonucunda AMOS 23 programinda analiz edilen veriler neticesinde doğrulayıcı faktör analizi path diyagramı Şekil 2'de verilmiştir. 


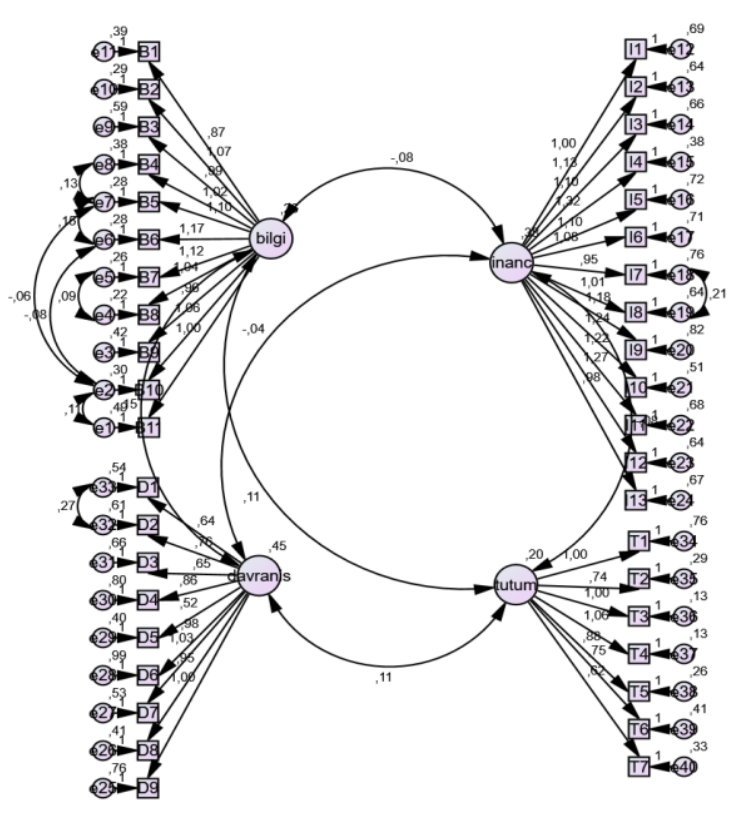

Şekil 2. Doğrulayıcı Faktör Analizi Path Diyagramı

Araştırma dâhilinde alınan katılımcıların demografik bilgileri Tablo 2'de verilmiştir. 105'inin $(\% 49,1)$ erkek, 109'unun $(\% 50,9)$ kadın olduğu görülmektedir. Katılımcıların yaş durumlarına göre dağılımları değerlendirildiğinde ise; 55 'inin $(\% 25,7) 20$ 29 yaş grubu, 102'sinin (\%47,7) 30-39 yaş grubu, 40'ının (\%18,7) 40-49 yaş grubu, 14'ünün $(\% 6,5)$ 50-59 yaş grubu, 3'ünün $(\% 1,4) 59$ ve üzeri yaş grubu içerisinde olduğu görülmektedir. Katılımcıların bulunduğu yerlere göre dağılımları ise Tablo 2'ye göre değerlendirildiğinde ise; 70'inin $(\% 32,7)$ Merkez ilçesinde, 47'sinin $(\% 22,0)$ Kelkit ilçesinde, 35'inin $(\% 16,4)$ Şiran ilçesinde, 23 'ünün $(\% 10,7)$ Torul ilçesinde, 25'inin $(\% 11,7)$ Kürtün ilçesinde, 14'ünün $(\% 6,5)$ Köse ilçesinde çalıştığı görülmektedir.

Araştırmaya katılanların çevre dersi alma durumlarına göre dağılımları incelendiğinde; 120'si $(\% 56,1)$ çevre dersi aldığını, 94'ü $(\% 43,9)$ çevre dersi almadığını ifade etmiştir. Katılımcıların iklim değişikliği kelimesini daha önce duyma durumlarına göre dağılımları değerlendirildiğinde ise; 208'i $(\% 97,2)$ iklim değişikliği kelimesini daha önce duyduğunu, 6's1 $(\% 2,8)$ ise iklim değişikliği kelimesini daha önce duymadığını ifade etmiştir.
Tablo 2. Demografik Bilgiler

\begin{tabular}{|c|c|c|c|}
\hline Özellik & Dağılım & Sayı & $\begin{array}{c}\text { Yüzde } \\
(\%)\end{array}$ \\
\hline \multirow[t]{6}{*}{ Bulunduğu Yer } & Merkez & 70 & 32,7 \\
\hline & Kelkit & 47 & 22,0 \\
\hline & Şiran & 35 & 16,4 \\
\hline & Torul & 23 & 10,7 \\
\hline & Kürtün & 25 & 11,7 \\
\hline & Köse & 14 & 6,5 \\
\hline \multirow[t]{2}{*}{ Cinsiyet } & Kadın & 109 & 50,9 \\
\hline & Erkek & 105 & 49,1 \\
\hline \multirow[t]{5}{*}{ Yaş } & $20-29$ & 55 & 25,7 \\
\hline & $30-39$ & 102 & 47,7 \\
\hline & $40-49$ & 40 & 18,7 \\
\hline & $50-59$ & 14 & 6,5 \\
\hline & 59'un Üstü & 3 & 1,4 \\
\hline \multirow[t]{2}{*}{ Çevre Dersi Aldınız mı? } & Evet & 120 & 56,1 \\
\hline & Hayır & 94 & 43,9 \\
\hline \multirow{2}{*}{$\begin{array}{l}\text { İklim Değişikliği } \\
\text { Kelimesini Daha Önce } \\
\text { Duydunuz mu? }\end{array}$} & Evet & 208 & 97,2 \\
\hline & Hayır & 6 & 2,8 \\
\hline \multirow{5}{*}{$\begin{array}{c}\text { İklim Değişikliği İle İlgili } \\
\text { Ne Kadar Bilginiz } \\
\text { Olduğunu } \\
\text { Düşünüyorsunuz? }\end{array}$} & Çok Fazla & 17 & 7,9 \\
\hline & $\begin{array}{l}\text { Yeteri } \\
\text { Kadar }\end{array}$ & 132 & 61,7 \\
\hline & Biraz & 55 & 25,7 \\
\hline & Çok Az & 10 & 4,7 \\
\hline & Bilgim Yok & 0 & 0 \\
\hline \multirow{3}{*}{$\begin{array}{l}\text { İklimlerin Değiştiğini } \\
\text { Düşünüyor musunuz? }\end{array}$} & Evet & 208 & 97,2 \\
\hline & Hayır & 3 & 1,4 \\
\hline & Bilmiyorum & 3 & 1,4 \\
\hline
\end{tabular}

Araştırmaya dâhil edilen katılımcıların "İklim Değişikliği İle İlgili Ne Kadar Bilginiz Olduğunu Düşünüyorsunuz?" sorusuna; 17'si $(\% 7,9)$ çok fazla, 132'sinin $(\% 61,7)$ yeteri kadar, 55'i $(\% 25,7)$ biraz, 10'u $(\% 4,7)$ ise çok az olduğunu belirtmiştir. Araştırmaya dâhil edilen katılımcıların "İklimlerin Değiştiğini 
Düşünüyor musunuz?" sorusuna; 208'i $(\% 97,2)$ evet, 3'ü $(\% 1,4)$ hayır, 3'ü $(\% 1,4)$ bilmiyorum diye belirtmiştir. Analize ilişkin sonuçlar Tablo 2'de belirtilmiştir.

Așağıda yer alan Tablo 3'e göre iklim değişikliği farkındalık, inanç, davranış, bilgi ve tutum puanı 1 ile 2,33 arasinda olanlar "düşük", 2,34 ile 3,67 arasında olanlar "orta", 3,68 ile 5 arasında olanlar "yüksek" olarak yorumlanmıştır. Araştırmamızda yer alan yedi farklı puan ortalaması (iklim değişikliği farkındalık, davranış, bilgi, tutum, inanç, belirsizlik inancı ve epistemik inanç puan ortalamaları) Tablo 3'e göre yorumlanmıştır.

Tablo 3. İklim Değişikliği Genel Puan Skalası

\begin{tabular}{cc}
\hline Puan & Düzeyi \\
\hline $1-2,33$ & Düşük \\
\hline $2,34-3,67$ & Orta \\
\hline $3,68-5$ & Yüksek \\
\hline
\end{tabular}

Sonuç olarak araştırmada elde ettiğimiz verilere göre araştırmaya dâhil edilen katılımcıların iklim değişikliği farkındalık puan ortalamaları $3,83 \pm 0,337$ olarak bulunmuştur. Tablo 3'teki skalaya göre 3,83'lük puan ortalaması yüksek düzey olarak kabul edilmiştir. Araştırmaya dâhil edilen katılımcıların iklim değişikliği farkındalık puan ortalamalarının alt faktörlere göre dağılımları değerlendirildiğinde; iklim değişikliği davranış puan ortalamaları $3,68 \pm 0,619$ olarak bulunmuştur. Tablo 4 'teki skalaya göre 3,68'lik puan ortalaması yüksek düzey olarak kabul edilmiştir. İklim değişikliği tutum puan ortalamaları 4,56 $\pm 0,443$ olarak bulunmuştur. Tablo 3'teki skalaya göre 4,56'lık puan ortalaması yüksek düzey olarak kabul edilmiştir. İklim değişikliği bilgi puan ortalamaları 3,98 $\pm 0,562$ olarak bulunmuştur. Tablo 3'teki skalaya göre 3,98'lik puan ortalaması yüksek düzey olarak kabul edilmiştir. İklim değişikliği inanç puan ortalamaları 3,09 $\pm 0,378$ olarak bulunmuştur. Tablo 3'teki skalaya göre 3,09'lik puan ortalaması orta düzey olarak kabul edilmiştir. İklim değişikliği belirsizlik inancı puan ortalamaları 2,00 $\pm 0,732$ olarak bulunmuştur. Tablo 3'teki skalaya göre 2,00'lik puan ortalaması düşük düzey olarak kabul edilmiştir. İklim değişikliği epistemik inancı puan ortalamaları $4,18 \pm 0,457$ olarak bulunmuştur. Tablo 3'teki skalaya göre 4,18 'lik puan ortalaması yüksek düzey olarak kabul edilmiştir.

Korelasyon analizi sonucunda elde edilen bulgulara göre, iklim değişikliği farkındalığını etkileyen unsurlar arasında pozitif yönde ilişki olduğunu söylemek mümkündür. Sonuca göre bağımsız değişkenler (Bilgi Puan Ortalaması, Tutum Puan Ortalaması, Davranış Puan Ortalaması, İnanç Puan Ortalaması) arasındaki ilişkiler $\mathrm{p}<0,01$ düzeyinde anlamlıdır. Korelasyon katsayıları incelendiğinde en güçlü ilişki bilgi puan ortalamas1 ve tutum puan ortalamas1 değişkenleri arasındadır. $(\mathrm{r}=.430, \mathrm{p}<0.01) . \mathrm{Bu}$ iki değişken arasındaki ilişki pozitif yönlü, zayıf kuvvette ve anlamlıdır. Tablo 4'te korelasyona ilişkin bilgiler detaylı şekilde verilmiştir.

Tablo 4. Korelasyona İlişkin Bilgiler

\begin{tabular}{ccccc}
\hline & $\begin{array}{c}\text { Bilgi Puan } \\
\text { Ortalaması }\end{array}$ & $\begin{array}{c}\text { Tutum Puan } \\
\text { Ortalaması }\end{array}$ & $\begin{array}{c}\text { Davranış } \\
\text { Puan } \\
\text { Ortalaması }\end{array}$ & $\begin{array}{c}\text { Ínanç Puan } \\
\text { Ortalaması }\end{array}$ \\
\hline $\begin{array}{c}\text { Bilgi Puan } \\
\text { Ortalaması }\end{array}$ & 1 & & \\
\hline $\begin{array}{c}\text { Tutum Puan } \\
\text { Ortalaması }\end{array}$ &, $430 * *$ & 1 & \\
\hline $\begin{array}{c}\text { Davranıs Puan } \\
\text { Ortalaması }\end{array}$ &, $365^{* *}$ &, $280^{* *}$ & 1 & \\
\hline $\begin{array}{c}\text { Inanç Puan } \\
\text { Ortalaması }\end{array}$ &, 095 &, 063 &, $217 * *$ & 1 \\
\hline$* p<0,01$ & & & \\
\hline
\end{tabular}

Aşağıda belirtilen Tablo 5'e göre regresyon katsayısı $\mathrm{p}<0,05$ olduğu için ve $\% 5$ anlamlılık seviyesinde çoklu regresyon katsayısı geçerlidir. Yani bağımsız değişkenler ile bağımlı değişken arasındaki iliş̧i anlamlı olduğu ve tüm bağımsız değişkenlerin birlikte bağımlı değişkenin \%34,9'unu açıkladığı söylenebilir. Tabloya bakıldığında beta değeri 0,223 ve $p<0,05$ olduğu için tutum puan ortalaması, beta değeri 0,123 ve $p<0,05$ olduğu için davranış puan ortalaması ve beta değeri 0,451 ve $p<0,05$ olduğu için epistemik puan ortalaması, bilgi puan ortalaması üzerinde etkilidir. Ayrıca beta değeri - 0,072 ve $p>0,05$ olduğu için belirsizlik puan ortalaması 0,05 anlamlılık düzeyinde 
bilgi puan ortalaması üzerinde etkili değildir. Tablo 5'te regresyon analizi sonucu daha ayrıntılı şekilde verilmiştir.

Tablo 5. Regresyona İliş̧kin Bulgular

\begin{tabular}{cccc}
\hline Değişkenler & $\begin{array}{c}\text { Standartlaştırılmamış } \\
\text { Beta Katsayıları }\end{array}$ & T & Sig T \\
\hline $\begin{array}{c}\text { Tutum Puan } \\
\text { Ortalaması }\end{array}$ &, 223 & 2,653 & $\mathrm{p}<, 05$ \\
\hline $\begin{array}{c}\text { Belirsizlik } \\
\text { Puan } \\
\text { Ortalaması }\end{array}$ &, 123 & 2,132 & $\mathrm{p}<, 05$ \\
\hline $\begin{array}{c}\text { Davranış } \\
\text { Puan } \\
\text { Ortalaması }\end{array}$ &,-072 & $-1,596$ & $\mathrm{p}<, 05$ \\
\hline $\begin{array}{c}\text { Epistemik } \\
\text { Puan } \\
\text { Ortalaması }\end{array}$ &, 451 & 5,085 & $\mathrm{p}<, 05$ \\
\hline Not: $R:, 59 ; R$ Square: , 34; Adjusted R Square: , 33; F: 28,02; $p<0,05$
\end{tabular}

Katılımcıların iklim değişikliği epistemik inancı puan ortalamaları, çevre dersi alma durumlarına göre değerlendirildiğinde, istatistiksel olarak anlamlı bir fark bulunmuştur $(p<0,05)$. Çevre dersi alan ilkokul öğretmenlerinin iklim değişikliği epistemik inancı puan ortalamalarının $4,24 \pm 0,432$ olduğu görülmektedir. Bu iklim değişikliği epistemik inancı puan ortalaması tablo 3 'teki skalaya göre yüksek seviye olarak bulunmuştur. Çevre dersi alan ilkokul öğretmenlerinin iklim değişikliği epistemik inancı puan ortalamalarının çevre dersi almayan ilkokul öğretmenlerine göre daha yüksek olduğu görülmektedir.

Katılımcıların iklim değişikliği farkındalık puan ortalamaları, yaşlara göre değerlendirildiğinde, istatistiksel olarak anlamlı bir fark bulunmuştur $(\mathrm{p}<0,05) .40$ yaş ve üzerinde olan ilkokul öğretmenlerinin iklim değişikliği farkındalık puan ortalamalarının $\quad 3,91 \pm 0,351 \quad$ olduğu görülmektedir. $\mathrm{Bu}$ iklim değişikliği farkındalık puan ortalaması tablo 3'teki skalaya göre yüksek seviye olarak bulunmuştur. 40 yaş ve üzerinde olan ilkokul öğretmenlerinin iklim değişikliği farkındalık puan ortalamalarının 39 yaş ve altında olan ilkokul öğretmenlerine göre daha yüksek olduğu görülmektedir.

Katılımcıların iklim değişikliği bilgi puan ortalamaları, yaşlara göre değerlendirildiğinde, istatistiksel olarak anlamlı bir fark bulunmuştur $(p<0,05)$. 40 yaş ve üzerinde olan ilkokul öğretmenlerinin iklim değişikliği bilgi puan ortalamalarının $4,11 \pm 0,531$ olduğu görülmektedir. Bu iklim değişikliği bilgi puan ortalaması tablo 3 'teki skalaya göre yüksek seviye olarak bulunmuştur. 40 yaş ve üzerinde olan ilkokul öğretmenlerinin iklim değişikliği bilgi puan ortalamalarının 39 yaş ve altında olan ilkokul öğretmenlerine göre daha yüksek olduğu görülmektedir.

Katılımcıların iklim değişikliği davranış puan ortalamaları, cinsiyetlere göre değerlendirildiğinde, istatistiksel olarak anlamlı bir fark bulunmuştur $(\mathrm{p}<0,05)$. Kadın ilkokul öğretmenlerinin iklim değişikliği davranış puan ortalamalarının $3,77 \pm 0,564$ olduğu görülmektedir. Bu iklim değişikliği davranış puan ortalaması Tablo 3'teki skalaya göre yüksek seviye olarak bulunmuştur. Kadın ilkokul öğretmenlerinin iklim değişikliği davranış puan ortalamalarının erkek ilkokul öğretmenlerine göre daha yüksek olduğu görülmektedir.

Katılımcıların iklim değişikliği bilgi puan ortalamaları, bulunduğu yerlere göre değerlendirildiğinde, istatistiksel olarak anlamlı bir fark bulunmuştur $(\mathrm{p}<0,05)$. Gümüşhane ili Şiran ilçesinde çalışan ilkokul öğretmenlerinin iklim değişikliği bilgi puan ortalamalarının $\quad 4,09 \pm 0,629 \quad$ olduğu görülmektedir. Bu iklim değişikliği bilgi puan ortalaması Tablo 3'teki skalaya göre yüksek seviye olarak bulunmuştur. Şiran'da çalışan ilkokul öğretmenlerinin iklim değişikliği bilgi puan ortalamalarının diğer ilçelerde çalışan ilkokul öğretmenlerine göre daha yüksek olduğu görülmektedir.

Katılımcıların iklim değişikliği epistemik inancı puan ortalamaları, bulunduğu yerlere göre değerlendirildiğinde, istatistiksel olarak anlamlı bir fark bulunmuştur. $(\mathrm{p}<0,05)$. Kürtün'de çalışan ilkokul öğretmenlerinin iklim değişikliği epistemik inancı puan ortalamalarının $\quad 4,32 \pm 0,419 \quad$ olduğu görülmektedir. Bu iklim değişikliği epistemik inancı puan ortalaması Tablo 3'teki skalaya göre yüksek seviye olarak bulunmuştur. Kürtün'de çalışan ilkokul öğretmenlerinin iklim değișikliği epistemik inancı puan ortalamalarının diğer ilçelerde çalışan ilkokul 
öğretmenlerine göre daha yüksek olduğu görülmektedir.

Eagles ve Demare 1999 yılında 6. Sinıf öğrencilerinin çevresel tutumuna etki eden faktörleri incelemişlerdir. Araştırma Wilmot Kıdemli Devlet Okulu'nda 72 öğrenciyle gerçekleştirilmiştir. Araştırma sonucunda cinsiyetin çevresel tutum üzerine etkisi incelenmiştir. Sonuç olarak kadınlarda oran yüksek çıkmış olsa da anlamlı bir farka rastlanmamıştır. İlkokul öğretmenlerinde cinsiyetin tutum üzerinde etkisi incelendiğinde aynı şekilde anlamlı bir farka rastlanmamıştır. Eagles ve Demare'nin çalışmasıyla bu noktada ulaşılan sonuçlar paralellik göstermektedir ${ }^{26}$

Ortaöğretim öğrencilerinin çevreye yönelik tutumları ve çevre dersiyle ilişkisini incelemek üzere Uzun ve Sağlam tarafindan Ankara ilinde inceleme yapılmıştır. Araştırma 2007 yılında Çankaya ilçesinde çeşitli ortaöğretimlerde $\quad$ okuyan 1013 öğrenciylegerçekleştirilmiştir.Veri toplama aracı olarak çevre tutum ölçeği ve çevre bilgi testi kullanılmıştır. Araştırmanın önemli sonuçlarından birisi çevre ve insan dersi alan öğrencilerin çevreye yönelik bilgi ve tutumları almayanlara göre daha yüksek ve anlamlı çıkmıştır. Gümüşhane'de ilkokul ögrretmenlerinde ise çevre dersi alan ve almayan öğretmenlerin bilgi ve tutum ortalamaları arasında anlamlı bir farka rastlanmamıştır. ${ }^{27}$

Oluk ve Oluk' un 2007 yılında Celal Bayar Üniversitesi'nde, eğitim fakültesinde 24 öğrenciyle yarı yapılandırılmış yöntem uyarınca birebir görüşme tekniğiyle yapmış olduğu araştırmada öğrencilerin \%66's1 iklimlerin değiştiğini belirtmiştir. Gümüşhane'de bulunan ilkokul öğretmenleri ise $\% 97$ oranında iklimlerin değiştiğini düşünmektedir. Arada oluşan farkın ise iklim değişikliğinin etkilerinin her geçen yıl daha da fazla hissedilmesi, son yillarda en sicak yılların yaşanmasının bu oranın artmasında etkili olduğu düşünülmektedir. ${ }^{28}$

Gürbüz ve Çakmak 2012 yılında, biyoloji bölümü öğrencilerinin çevreye yönelik tutumlarını incelemiştir. Araştırma Dicle Üniversitesi Ziya Gökalp Eğitim Fakültesinde
119 öğrenciyle yapılmıştır. Veri Toplama arac1 olarak 5'li likert tipi 27 maddeden oluşan çevresel tutum ölçeği kullanılmıştır. Gürbüz ve Çakmak biyoloji bölümü öğrencilerinin çevreye yönelik tutumları genel olarak olumlu bulunmuştur. $\mathrm{Bu}$ noktada çalışmanın sonuçları araştırmamızın sonuçlarıyla paraleldir. ${ }^{29}$

Eroğlu ve Aydoğdu 2016 yılında, fen bilgisi öğretmenliği adaylarının küresel ısınma hakkındaki bilgi düzeylerini belirlemeye yönelik bir araştırma gerçekleştirmiştir. Çalışmada Eroğlu ve Aydoğdu kendi geliştirdikleri kapalı uçlu, likert tipi anket kullanmışlardır. Araştırma bir devlet üniversitesinde, normal ve ikinci öğrenimde eğitim gören 271 lisans öğrencisiyle yapılmıştır. Sonuç olarak artan sera gazı salınımı ve insan faaliyetlerinin küresel 1sınmayı arttırıcı yöndeki etkisinin, ögrenciler tarafından genel olarak bilindiği belirlenmiştir. Çalışmamız, Eroğlu ve Aydoğdu'nun çalışmasıyla benzer sonuçlara sahiptir. Sera gazının iklim değişikliği ve buna paralel olarak küresel isınmanın bir nedeni olduğu, ilkokul öğretmenlerinin vermiş olduğu, \%48 katıliyorum, \%36 kesinlikle katıliyorum cevaplariyla onaylanmıştır. Ayrıca insan faaliyetlerinin küresel ısınmaya bir etkisi olmadığına ilişkin soruya katılimcilar \%68 kesinlikle katılmiyorum, \%20 kesinlikle katılmıyorum cevaplarını vermiştir. Sonuç olarak Eroğlu ve Aydoğdu'nun çalışmasıyla benzer sonuçlar çıkmıştır. ${ }^{30}$

Tok ve arkadaşları 2017 yılında sınıf öğretmeni adaylarının iklim değişikliği farkındalığını incelemiştir. Çalışma, İç Anadolu ve Ege Bölgesinde bulunan iki devlet üniversitesinde toplamda 270 sinıf öğretmeni adayıyla gerçekleştirilmiştir. Tok ve arkadaşları araştırmada iklim değişikliğine yönelik farkındalık ölçeği kullanmışlardır. Araştırmada dikkat çeken sonuçlardan birisi iklim değişikliğinin çeşitli hastalıkları arttırıcı yöndeki etkisine dair sınıf öğretmenlerinin farkındalık ortalaması genel olarak düşük düzeyde çıkmıştır. İlkokul öğretmenleriyle gerçekleştirdiğimiz araştırmanın sonucunda hastalıklara ilişkin 3 farklı türde soru 
yöneltilmiştir. İlk olarak iklim değişikliğinin sebep olacağı sivrisinek ve kene artışının önümüzdeki yıllarda hastalık sayılarını arttıracağına ilişkin soruya katılımcılar, \%46 katıliyorum, \%20 kesinlikle kat1lıyorum cevabını vermiştir. İklim değişikliğinin salgın hastalıkları arttırıcı etkisine katılımcılar, \%44 katılıyorum, \%22 kesinlikle katıliyorum cevabını vermiştir. İklim değişikliğiyle beraber hava şartlarının bozulması ve sıcaklık artışının akciğer ve kalp hastalıklarını arttıracağı yönündeki soruya katılımcılar, $\% 44$ kat1liyorum, \%22 kesinlikle katılıyorum cevabını vermiştir. Tok ve arkadaşlarının çalışmasına göre, bizim yaptığımız araştırmada çıkan sonuçlar daha yüksek düzeydedir. Gümüşhane'deki ilkokul öğretmenleri iklim değişikliğinin hastalıkları arttırıcı yöndeki etkisinin daha çok farkındadırlar. ${ }^{31}$

Arık ve Yılmaz 2017 yılında yapmış oldukları çalışmada, Fen Bilimleri Öğretmen Adaylarının Çevre Sorunlarına Yönelik Tutumlart ve Çevre Kirliliğine Yönelik Metaforik Algılarını incelemiştir. Çalışma Tokat Gaziosmanpaşa Üniversitesi'nde gerçekleştirilmiştir. Toplamda 132 fen bilgisi öğretmen adayıyla çalışılmıştır. Veri toplama aracı olarak çevre tutumları ölçeği ve metafor toplama formu kullanılmıştır. Araştırma sonucunda fen bilgisi öğretmen adaylarının çevreye yönelik tutumları orta seviyede çıkmıştır. Araştırmamızda ise çevre sorularına yer verdiğimiz tutum bölümünde Gümüşhane'de görev yapan ilkokul öğretmenlerinin çevreye yönelik tutumları yüksek düzeyde çıkmıştır. ${ }^{32}$

Küresel ısınma ve iklim değişikliği birbiriyle ilişkili kavramlardır. Birbirini tetikleyici bu etkenlerden küresel 1sınmayla ilgili olarak 2018 yılında Akgün ve arkadaşları tarafindan inceleme gerçekleştirilmiştir. Çalışma 36 çevre mühendisliği öğrencisiyle yapılmıştır. Çalışmada amaç çevre mühendisliği öğrencilerinin küresel 1sınmayla ilgili görüşlerinin eleştirel düşünme eğilimleri ve duygusal zekâ açısından değerlendirmektir. Öğrencilerden tanıtıcı bilgi formu, California Eleştirel Düşünme Eğilimleri, Gözden Geçirilmiş Schutte Duygusal Zekâ ölçeklerini yanıtlamaları istenmiştir. Çalışmanın sonucuna göre öğrenciler küresel isınma kavramını \%41,7'si televizyonda, \%27,8'i okulda, \%19,4'ü internetten duyduklarını belirtmiştir. Bizim çalışmamız da ise ilkokul öğretmenleri iklim değişikliğini nereden duydunuz sorusuna \%93,9'u televizyondan, $\% 88,8^{\prime} \mathrm{i}$ internetten, \%53,3'ü ise okul ve üniversiteden duyduklarını belirtmişlerdir. ${ }^{33}$

\section{SONUÇ VE ÖNERILLER}

İlkokul öğretmenlerine yönettiğimiz iklim değişikliğinin etkilerini azaltmak ve mücadele edebilmek için neler yapabiliriz sorusuna öğretmenlerin yazmış olduğu öneriler aşağıda belirtilmiștir.

- Problemin gerçekliği herkes tarafından kabul edilmelidir.

- Yeşil alanlar korunmalıdır.

- Fosil yakitların kullanımı azaltılmalıdır.

- Alternatif enerji kaynakları kullanmalıdır.

- Toplum, eğitim ve çeşitli etkinliklerle bilinçlendirilmelidir.
- Geri dönüşüme daha çok önem verilmelidir.

- Tüm dünya bu konuda ortak şekilde hareket etmelidir.

- Bireysel olarak da iklim değişikliği konusunda herkes üzerine düşeni yapmalidir.

- İklim değişikliğinin etkilerine karş1 yasal yaptırımlar ve antlaşmalar uygulanmalidir.

- Enerji (su, elektrik) kullanımına dikkat edilmelidir.

- Sera gazı salınımına karşı gerekli tedbirler alınmalıdır. 
- Tüm sektörlerde devlet olarak tasarrufa gidilmelidir.

- Atıkların kontrolü ve ayrıştırılması sağlanmalıdır.

- İklim değişikliği ile ilgili farkındalık oluşturulmalıdır.

- Doğayı ve doğal kaynakları korumak için daha fazla tedbir alınmalıdır.

- Doğa üzerinde yaratılan insan kaynaklı tahribatın önüne geçmek için önlemler alınmalıdır.

- Hükümet, iklim değişikliği ile mücadele edebilmek için yapılan çalışma ve projelere daha çok destek vermelidir.

- Ekosistemi koruyabilmek adına çevre ve hava kirliliğine karşı daha çok önlem alınmalıdır.

- Sanayileşmenin getirdiği kirlilik ve tahribata karşı tedbirler alınmalıdır.

- Uzmanlar bu konuda çalışmalarıyla insanları daha fazla aydınlatmalıdır.

- Nükleer enerji kullanımı ve denemelerine sinırlandırma getirilmelidir.

- Ebeveynler çocuklarına iklim değişikliğinin önemiyle ilgili erken yaşta eğitim vermelidir.

- İş yerleri ve ortak yaşam alanlarında bilgilendirici çalışmalar yapılmalı ve afiş asılmalıdır. Kamu spotu çalışmalarında iklim değişikliğine yer verilmelidir.

- Etrafimızdaki insanları bu konuyla ilgili uyarmalı ve gerekli bilgi verilmelidir.

- İklim değişikliği ile ilgili eğitimler öğrencilere teorik eğitimin yanında, uygulamalı olarak da verilmelidir. Bunun için devlet taraflı destek sağlanmalıdır.

- Gelişmiş ülkeler bencil tutumlarından vazgeçmelidir.
- Medya bu konuya geniş yer vermelidir.

- İlkokul müfredatına iklim değişikliği ve etkileriyle ilgili ders eklenmelidir.

- Tek bir kiși kalmayana kadar, tüm insanlarda duyarlılığın oluşması sağlanmalıdır.

- Hızlı ve çarpık kentleşmenin önüne geçilmelidir. Yanlış arazi kullanımına izin verilmemelidir.

- Ozon tabakasını etkileyen maddelerin kullanımına sınırlama getirilmelidir.

- Uluslararası örgütler ve sivil toplum kuruluşları faaliyetlerini arttırmalıdır.

Genel olarak çalışma sonucunda elde ettiğimiz verilere göre, ilkokul öğretmenlerinin, iklim değişikliğine ilişkin önerileri yukarıda belirtildiği şekildedir. Konuyla ilgili yapılan yorumlara bakıldığında Gümüşhane ili genelinde görev yapan ilkokul öğretmenlerinde farkındalıkları ve konuya verdikleri önem gayet olumludur.

Bir afet olarak küresel iklim değişikliğini değerlendirecek olursak, iklim değişikliğinin etkileri günümüzde gitgide hissedilmeye başlanmıștır. Özellikle risk evresi iklim değişikliği açısından çok büyük bir öneme sahiptir. $\mathrm{Bu}$ dönemde yapılan tüm önemli adımlar geleceğimize dair birer yatırımdır.

İklim değişikliğinin bireyler tarafından biliniyor olmasının tutum üzerinde pozitif yönde etkisi olduğu yukarıda belirtilmiş olunan korelasyon tablosunda gösterilmiştir. $\mathrm{Bu}$ sonuca göre iklim değişikliği ile ilgili insanların bilgi düzeyini artırıcı yönde yapacağımız çalışmaların, davranış ve tutum olarak olumlu yönde dönüş sağlayacağını düşünmekteyiz.

Özellikle sanayileşmede öncü olan ülkelere bu konuda büyük sorumluluklar düşmektedir. Alınacak olan tedbirler bağlamında güçlü sanayiye sahip olan ülkeler öncü olmalıdır. Çünkü yapılan bilimsel çalışmalar ve IPCC raporları şu an iklim değişikliğinin en önemli nedenlerinden biri olan sera gazı salınımında gelişmiş sanayiye 
sahip olan ülkelerin ilk sırada olduğunu göstermektedir.

Mevcut koşullar daha kötüye gitmeden atılacak olan adımlara hız verilmelidir. $\mathrm{Bu}$ adımlarda eğitim önemli bir yere sahiptir. Çocuklarda şimdiden oluşturulacak olan iklim değişikliği bilinci, koruma aşamasında alınacak olan diğer önlemler için temel bir taş olacaktır. Devlet kurumları iklim değişikliği ile ilgili çalışmalarında hem öğretmenlerde hem öğrencilerde iyileştirmeye gitmelidir. Öğretmenler iklim değișikliği konusunda kişisel olarak eğitim almalı, öğrencilerin iklim değişikliği bilincini arttırmak için ders müfredatıyla ilgili düzenlemeye gidilebilir.
Farkındalık sahibi olarak yetişecek her nesil, bir diğer neslin temeli olacaktır.

Eğitim konusunda yapılacak olan çalışmalarda akademik düzeye kadar gidilebilir. Afetleri önlemeye ilişkin yapılan planlarda iklim değişikliği ile ilgili revize yapılmalı ve planların içeriğinde iklim değişikliğine daha fazla önem verilmelidir. Risk evresiyle ilgili tedbirler geliştirilmelidir. Afet ve Acil Durum Başkanlığı önlem ve tedbir bakımından yapacağı çalışmaları geliștirebilir. Yapacakları planlar, akademik çalıșmalar ve eğitimlerle ilgili devlet kurumlarına ve iklim değişikliğinin önemine dikkat çeken kuruluşlara destek ve yol gösterici olması gerektiği düşünülmektedir.

\section{KAYNAKLAR}

1. Kadığlu M. (2012). Türkiye'de İklim Değişikliği Risk Yönetimi, Birinci Baskı, Türkiye'nin İklim Değişikliği II. Ulusal Bildiriminin Hazırlanması Projesi Yayını, Ankara.

2. Kılıç C. (2009). "Küresel İklim Değişikliği Çerçevesinde Sürdürülebilir Kalkınma Cabaları ve Türkiye", Cumhuriyet Üniversitesi İktisadi ve İdari Bilimler Dergisi, $10(2), 19-41$

3. Cromwell J E., Smith J.B. and Raucher R.S. (2007) Implications of Climate Change for Urban Water Utilities, Association of Metropolitan Water Agencies, Washington.

4. Kadığlu M. (2008). "Günümüzden 2100 Yılına Kürese İklim Değişimi.”, TMMOB İklim Değişimi Sempozyumu Bildiriler Kitabı, 25-45.

5. Özmen T.(2009). "Sera Gazı, Küresel Isınma ve Kyoto Protokolü.”, İMO Dergisi, 453 (1), 42-46.

6. IPCC 1996a. Climate Change 1995, The Science of Climate Change. Contribution of Working Group I to the Second Assessment Report of the Intergovernmental Panel on Climate Change, Houghton J, T., et al., eds., WMO/UNEP. Cambridge University Press, New York.

7. Devlet Planlama Teșkilatı. (2000). İklim Değișikliği Özel İhtisas Komisyon Raporu, Sekizinci Beş Yıllık Kalkınma Planı, Ankara.

8. Aksay C. S., Ketenoğlu O. and Kurt L., (2005). "Küresel Isınma ve İklim Değişikliği.”, Selçuk Üniversitesi Fen Fakültesi Fen Dergisi, 1 (25), 29-42.

9. Capra F. (1989). Batı Düșüncesinde Dönüm Noktası, Çev: Mustafa Armağan, Birinci Baskı, İnsan Yayınları, İstanbul

10. Intergovernmental Panel On Climate Change. (2001b) "TAR ClimateCChangeC2001:CSynthesisCReport", https://www.ipcc.ch/site/assets/uploads/2018/05/SYR_TA R full report.pdf, Erişim Tarihi: 20.12.2018.

11. European

Enviroment Agency.Chttps://www.eea.europa.eu/tr/isaretler/isaretler2015/makaleler/iklim-degisikliginin-etkilerini-azaltmak, Erişim Tarihi: 20.02.2019

12. Kaya Y. (2018), "İklim Değişikliğine Karșı Kentsel Kırılganlık: İstanbul İçin Bir Değerlendirme”, International Journal of Social Inquiry, 11 (2), 219-257.
13. Avrupa Komisyonu. (2010). “AB Öncülüğünde İklim Değisikliği ile "AB̈cadele", https://www.avrupa.info.tr/fileadmin/Content/publications /tr/AB cevre kitap.pdf, Erişim Tarihi: 20.03.2019.

14. Gıddens A. (2013). İklim Değișikliği Siyaseti, Çev: Erhan Baltacı, Birinci Baskı, Phoenıx Yayınevi, Ankara.

15. Coertjens L., Boeve-de pauw J., De Mayaer S. and Van petegem P. (2010). "Do Schools Make A Difference In Their Students' Environmental Attıtudes And Awareness? Evidence From Pisa 2006". International Journal of Science and Mathematics Education, 8 (3), 497-522.

16. Hiğde E. (2014). 'Fen Bilimler Öğretmen Adaylarının Cevre Dostu Davranışlarının Belirlenmesi: İklim Değişikliği Örneği, Orta Doğu Teknik Üniversitesi Sosyal Bilimler Enstitüsü, Yüksek Lisans Tezi, Ankara.

17. Seçer İ. (2015). SPSS ve LISREL ile Pratik Veri Analizi, İkinci Baskı, Anı Yayıncılık, Ankara.

18. Hu L. and Bentler P. M. (1999). "Cutoff Criteria for Fit Indexes in Covariance Structure Analysis: Conventional Criteria Versus New Alternatives." Structural Equation Modeling: A Multidisciplinary Journal, 6 (1), 1-55.

19. Klıne R. B. (2005). Principle and Practice of Structural Equation Modelling. Second Edition, New York: The Guilford Press, New York.

20. Plichta S.B. and Kelvin E. (2013). Munro's Statistical Methods for Health Care Research, Wolters Kluwer Health/Lippincott, Williams and Wilkins.

21. Shevlin M. and Miles J. N.V. (1998). "Effects of Sample Size, Model Specification and Factor Loadings on The GFI in Confirmatory Factor Analysis.", Personality and Individual Differences, 25 (1), 85-90.

22. Schermelleh-engel K., Moosbrugger $H$. and Müller $H$. (2003). "Evaluating the Fit of Structural Equation Models: Tests of Significance and Descriptive Goodness of fit Measures.", Methods of Psychological Research online, 8 (2), 23-74.

23. Capık C. (2014). "Geçerlik ve güvenirlik çalısmalarında doğrulayıcı faktör analizinin kullanımı.”, Anadolu Hemșirelik ve Sağlık Bilimleri Dergisi, 17 (3), Sayfa: 196 205 
24. Schreiber J. B., Nora A., Stage F. K. ,Barlow E. A. And King J. (2006). "Reporting Structural Equation Modeling and Confirmatory Factor Analysis Results: A Review.", The Journal of educational research, 99 (6), 323-338.

25. Kılıç A. F. ve Koyuncu İ. (2017). "Ölçek Uyarlama Çalıșmalarının Yapı Geçerliği Açısından İncelenmesi." Pegem Atıf İndeksi, 415-438.

26. Eagles P. F. J. and Demare R. (1999). "Factors Influencing Chldren's Environmental Attitudes", The Journal of Environmental Education, 30 (4), 33-37.

27. Uzun N. ve Sağlam N. (2007). “Ortaöğretim Öğrencilerinin Çevreye Yönelik Bilgi Ve Tutumlarına "Çevre Ve İnsan" Dersi İle Gönüllü Çevre Kuruluşlarının Etkisi”, Hacettepe Üniversitesi Eğitim Fakültesi Dergisi, 33, 210-218.

28. Oluk, E. A., \& Oluk, S. (2007). "'Yüksek Öğretim Öğrencilerinin Sera Etkisi, Küresel Isınma ve İklim Değișikliği Algılarının Analizi’’ Dokuz Eylül Üniversitesi Buca Eğitim Fakültesi Dergisi, (22).

29. Gürbüz H. ve Çakmak M.(2012). "Biyoloji Eğitimi Bölümü Öğrencilerinin Çevreye Yönelik Tutumlarının İncelenmesi”, Dicle Üniversitesi Ziya Gökalp Eğitim Fakültesi Dergisi, 19, 162-173.
30. Eroğlu B. ve Aydoğdu M. (2016). "Fen Bilgisi Öğretmen Adaylarının Küresel Isınma Hakkındaki Bilgi Düzeylerinin Belirlenmesi", Uludağ Üniversitesi Eğitim Fakültesi Dergisi, 29 (2), 345-374.

31. Tok G., Cebesoy Ü.B. ve Bilican K. (2017). "Sınıf Öğretmeni Adaylarının İklim Değişikliği Farkındalıklarının İncelenmesi.”, Batı Anadolu Eğitim Bilimleri Dergisi, 8 (2), 23-36.

32. Arık S. ve Yılmaz M. (2017). "Fen Bilimleri Öğretmen Adaylarının Çevre Sorunlarına Yönelik Tutumları ve Çevre Kirliliğine Yönelik Metaforik Algıları”, Kastamonu Eğitim Dergisi, 25 (3), 1147-1164.

33. Malak Akgün B., Balık N. ve Akgün M. (2018). “Çevre Mühendisliği Öğrencilerinin Küresel Isınma Konusundaki Görüşlerinin Eleştirel Düşünme Eğilimleri ve Duygusal Zekâ Düzeyleri Açısından Değerlendirilmesi." Eğitimde Nitel Araștırmalar Dergisi - Journal of Qualitative Research in Education, 6 (3), 34-61 